\title{
Alkaline Pre-Treatment of Coal Fly Ash as Bio-Silica Fertilizer
}

\author{
Laksmita P. Santi'1, Didiek H. Goenadi ${ }^{1}$, Donny N. Kalbuadi ${ }^{1}$, Indah P. Sari ${ }^{1}$, Sulastri ${ }^{2}$ \\ ${ }^{1}$ Indonesian Research Institute for Biotechnology and Bioindustry, Bogor, Indonesia \\ ${ }^{2}$ PT Pupuk Kalimantan Timur, Bontang, Indonesia \\ Email: laksmita.santi@gmail.com
}

How to cite this paper: Santi, L.P., Goenadi, D.H., Kalbuadi, D.N., Sari, I.P. and Sulastri (2021) Alkaline Pre-Treatment of Coal Fly Ash as Bio-Silica Fertilizer. Journal of Minerals and Materials Characterization and Engineering, 9, 180-193.

https://doi.org/10.4236/jmmce.2021.92013

Received: February 11, 2021

Accepted: March 15, 2021

Published: March 18, 2021

Copyright $\odot 2021$ by author(s) and Scientific Research Publishing Inc. This work is licensed under the Creative Commons Attribution International License (CC BY 4.0).

http://creativecommons.org/licenses/by/4.0/

\begin{abstract}
This study deals with the pre-treatment of coal fly ash (CFA) by using alkaline substance to improve water solubility of $\mathrm{Si}$ which in turn readily available to the plants. Selected weight ratios of $\mathrm{CFA} / \mathrm{NaOH}(\mathrm{s}: \mathrm{s})$ were tested and the highest $\mathrm{H}_{4} \mathrm{SiO}_{4}$ yield ratio was selected for further study. X-ray diffraction and scanning electron microscopy analyses were performed to confirm the evidence of structural changes of the CFA upon alkaline treatment. To improve $\mathrm{SiO}_{2}$ dissolution, seven $\mathrm{Si}$-solubilizing fungi, i.e., Aspergillus niger BCC194, A. niger K0909, A. niger A1601, Trichoderma polysporum, T. viride, T. pseudokoningii, and Trichoderma spp, were each inoculated onto pre-treated ash. The results indicated that the relationships between ratio of $\mathrm{CFA} / \mathrm{NaOH}$ and total and soluble Si were linier $\left(\mathrm{R}^{2}=0.97^{* *}\right.$ and $0.96^{* *}$, respectively). Total $\mathrm{SiO}_{2}$ values range from $10.43 \%$ to $13.02 \%$, whereas soluble $\mathrm{Si}$ contents were $2.30 \%-2.64 \%$ improved about 300 times compared to un-treated CFA. Both XRD and SEM analyses indicated that alkaline treatment to CFA caused particle damages resulting in increasing soluble Si. Inoculation of pre-treated CFA by T. polysporum up to twelve days of incubation yielded the highest soluble Si. Each fungal species grown on Bunt \& Rovira solid media enriched with $\mathrm{CFA}$ as $\mathrm{Si}$-source expressed significantly different ability in solubilizing Si from CFA. Citric acid was shown to be stronger compared to acetic and oxalic acids in solubilizing Si from CFA.
\end{abstract}

\section{Keywords}

Soluble Si, Si-Solubilizing Fungi, Si Fertilizer, Silicic Acid

\section{Introduction}

As an attempt to implement a circular economy, a coal fly ash (CFA) originated 
from fertilizer power plant was intended to be an effective silicon $(\mathrm{Si})$ fertilizer. With considerably high silica $\left(\mathrm{SiO}_{2}\right)$ content, this material has very low water-soluble $\mathrm{Si}\left(\mathrm{H}_{4} \mathrm{SiO}_{4}\right)$. Silicon ( $\mathrm{Si}$ ) has got considerably intensive attention worldwide as new functional fertilizer. As the second largest abundant element on earth [1], this nutrient is required by almost all crops with various functions. However, the crops are capable of absorbing $\mathrm{Si}$ when it presents as a unique molecule, i.e., silicic acid $\left(\mathrm{H}_{4} \mathrm{SiO}_{4}\right)$ [2] [3]. On the other hand, $\mathrm{SiO}_{2}$ presents as insoluble material and its dissolution is governed by high $\mathrm{pH}$ (alkaline) condition. Although not considered as an essential element as NPK fertilizer, Si has a positive impact on plant development. Silicon fertilization has the potential to mitigate environmental stresses and soil nutrient depletion. Positive effects of $\mathrm{Si}$ in supporting better growth and improved yield of many important crops have been widely reported [4] [5] [6] [7]. Many efforts are then spent by many researchers in many countries to formulate the most effective product as Si fertilizer. Previously, we developed an acid-base extraction method of Bangka-Belitung quartz sand to improve water-soluble Si [8]. The formulated Si-fertilizer was shown to be very effective in improving growth and yield as well as water and nutrient use efficiencies of selected crops such as black soybean [9], rice paddy [10], sugarcane [11], corn [12], and oil palm [13].

In order to provide various diversification of Si-fertilizer raw material sources, coal fly ash (CFA) could be considered as a prospective material to be processed further as beneficial fertilizer. Many studies have been reported in relation to the characteristics of coal fly ash originated from a power plant facility. Among others, [14] [15] [16] [17] [18] indicated that CFA was dominated by silica $\left(\mathrm{SiO}_{2}\right)$, iron oxides $\left(\mathrm{Fe}_{2} \mathrm{O}_{3}\right)$, aluminum oxides $\left(\mathrm{Al}_{2} \mathrm{O}_{3}\right)$, and calcium oxides $(\mathrm{CaO})$. The content of soluble Si was however very low $(\ll 1 \%)$ and therefore it is necessary to process further the CFA as a new Si fertilizer to improve its soluble Si content. We are of the opinion that this effort could be achieved by employing both chemical and biological approaches. The chemical treatment could involve the reaction of CFA with alkaline substance such as sodium hydroxide $(\mathrm{NaOH})$ [8], whereas the biological activation could be employed by using silica-solubilizing microbes, particularly fungi [19].

As consequence of using coal in power plant of some fertilizer companies, $\mathrm{CFA}$ is generated in a considerably huge amount depending on the power generated by the plant. This phenomenon will to some extent create environmental problem since CFA in Indonesia is classified as toxic waste [20] and needs additional costs for handling it according to the safe waste management measures. By considering the chemical characteristics of the materials, as part of a circular economy program, CFA could be processed further to be a new Si-fertilizer. However, an effective process required needs to be established. We report here the process of alkaline pre-treatment on CFA and enrichment with selected Si-solubilizing fungus to formulate and evaluate the product specification according to existing regulation of commercial Si-fertilizer. 


\section{Material and Method}

\subsection{Coal Fly Ash Characterization}

The CFA material was obtained from PT Pupuk Kalimantan Timur in Bontang, East Kalimantan, Indonesia, for chemical characterization. The samples obtained had dark gray color and powder form (about 100 - 200 mesh size). Chemical analyses were conducted at Indonesian Research Institute for Biotechnology and Bioindustry in Bogor, West Java, Indonesia. The analyses included $\mathrm{pH}\left(\mathrm{H}_{2} \mathrm{O}\right)$, total organic $\mathrm{C}$ (Spectrophotometry), total $\mathrm{N}$ (Kjeldahl), $\mathrm{P}_{2} \mathrm{O}_{5}$ (25\% HCl-AAS), $\mathrm{K}_{2} \mathrm{O}$ (25\% HCl-AAS), $\mathrm{MgO}$ (25\% HCl-AAS), $\mathrm{CaO}$ (25\% HCl-AAS), Sulphur (AAS), total silica $\left(\mathrm{SiO}_{2}\right)$ (Gravimetry), soluble $\mathrm{Si}\left(\mathrm{H}_{4} \mathrm{SiO}_{4}\right)$ (Spectrophotometry), $\mathrm{Fe}_{2} \mathrm{O}_{3}$ (AAS), $\mathrm{Al}_{2} \mathrm{O}_{3}$ (AAS), cation exchange capacity (CEC) (Percolation-Titration), selected heavy metals $(\mathrm{Pb}, \mathrm{Cd}, \mathrm{As}, \mathrm{Hg}, \mathrm{Cr}$, and $\mathrm{Ni}$ ) (AAS), and water content (Gravimetry) employing standard analytical procedures [21].

\subsection{Si-Solubilizing Fungal (SSF) Isolate Preparation}

The silicate-solubilizing fungi (SSF) studied were cultured each in Bunt and Rovira solid standard media including selected strains of Aspergillus i.e., Aspergillus niger BCC F194, A. niger $\mathrm{K} 0909$ and A. niger A1601, and of Trichoderma i.e., Trichoderma sp., T. polysporum, T. viride, and T. pseudokoningii as collection of the Microbiology and Environmental Laboratory, IRIBB, Bogor [19]. A piece of inoculant SSF $(\varnothing=3 \mathrm{~mm}$ ) as a source of inoculum was grown on Bunt and Rovira solid medium containing $\left(\mathrm{L}^{-1}\right): 20 \mathrm{~g}$ glucose; $1.0 \mathrm{~g}$ peptone; $1.0 \mathrm{~g}$ yeast extract; $0.5 \mathrm{~g}\left(\mathrm{NH}_{4}\right)_{2} \mathrm{SO}_{4} ; 0.4 \mathrm{~g} \mathrm{~K}_{2} \mathrm{HPO}_{4} ; 0.1 \mathrm{~g} \mathrm{MgCl}_{2} ; 0.01 \mathrm{~g} \mathrm{FeCl}_{3} ; 250 \mathrm{~mL}$ soil extract; $20 \mathrm{~g}$ oxoid agar; $750 \mathrm{~mL}$ tap water; and $\mathrm{pH} 6.6$ - 7.0 as described by [22]. These media were supplemented with either $0.25 \%$ magnesium trisilicate $\left(\mathrm{Mg}_{2} \mathrm{O}_{8} \mathrm{Si}_{3}\right)$ or modified medium using CFA as sources of silicate.

\subsection{Silicate-Solubilizing Capacity of the SSF}

For assessment of Si-solubilizing capacity potential, petri dishes containing Bunt and Rovira solid medium at each initial $\mathrm{pH}$ condition were inoculated with each culture strain of SSF. The culture dishes were kept for seven days incubation at $28^{\circ} \mathrm{C}$. The solubilization halo's (translucent area surrounding colonies) diameter was measured after seven days incubation and the Solubilization Index (SI) expressed as halo diameter $(\mathrm{mm}) /$ colony diameter $(\mathrm{mm})$ was calculated [23]. The potential capacity of the strains studied was classified based on their SI as demonstrating low $(\mathrm{SI}<2.0)$, intermediate $(2.0 \leq \mathrm{SI}<4.0)$ and high $(\mathrm{SI} \geq 4.0)$ potential solubilization capacities.

\subsection{Effect of Ash/Alkaline Ratio on Soluble Si}

In this study, we modified the extraction method from the previously reported for quartz sand [8] by omitting the acid extraction $(\mathrm{HCl})$ and using alkaline substance $(\mathrm{NaOH})$ only to improve solubility of $\mathrm{SiO}_{2}$ in water $\left(\mathrm{H}_{4} \mathrm{SiO}_{4}\right)$. The main reason for this was to reduce the costs and still have sufficient soluble Si content 
as Si fertilizer. A 30 gram of CFA was activated by 30, 40, 50, and 60 grams $\mathrm{NaOH}(\mathrm{s})$, respectively, to obtain different ratio of $\mathrm{CFA} / \mathrm{NaOH}$. Four ratios of $\mathrm{CFA} / \mathrm{NaOH}$ (s) were evaluated and the most efficient ratio was selected based on soluble Si content. Each mixture was then heated on stove at $330^{\circ} \mathrm{C}$ while stirred manually until melted and the melted mixture was kept stirred until it dried out and cooled at room temperature [8]. Figure 1 shows typical physical appearances of original CFA and that after pre-treated with $\mathrm{NaOH}(\mathrm{s})$. Soluble Si was then determined from each ratio in two replicates by using spectrophotometer. Regression analysis was performed to determine relationship between soluble $\mathrm{Si}$ and the amounts of $\mathrm{NaOH}(\mathrm{s})$ added to CFA.

\subsection{Mineralogical Analyses}

\subsubsection{X-Ray Diffraction}

$\mathrm{X}$-ray diffraction (XRD) analysis was performed by using a random-oriented sample for both untreated and treated CFA employing XRD-6000 Shimadzu with $\mathrm{Cu} \mathrm{K} \alpha$ radiation at $40 \mathrm{kV}$ and $30.0 \mathrm{~mA}$ equipped with 1ow divergence and receiving slits and a graphite monochromator. The presence of minerals in the CFA sample was identified from random powder diffraction patterns following the procedures given by [24]. As adopted by [8] a continuous scan was applied in a horizontal scale ranging from $3^{\circ}$ to $90^{\circ} 2 \theta$ at a scan speed of $3^{\circ} 2 \theta \mathrm{min}^{-1}$ and a sampling pitch of 0.02 - 2 $\theta$. Calibration was done by using a 325-mesh $\mathrm{Si}$ powder standard of Shimadzu containing $990.0 \mathrm{~g} \cdot \mathrm{kg}^{-1} \mathrm{SiO}_{2}$.

\subsubsection{Electron Microscopy}

Scanning Electron Microscope (SEM) observation was carried out to treated and un-treated CFA samples. As reported by [8], the electron beam was accelerated through a high voltage $20 \mathrm{kV}$ and pass through a system of apertures and electromagnetic lenses to produce a thin beam of electrons. Prior to analysis, the samples were leveled with a special tool. After sputter coating the cast with 35 $\mathrm{nm}$ of gold-palladium (Au-Pd), electron micrographs were recorded using a Jeol JSM-5310LV SEM.
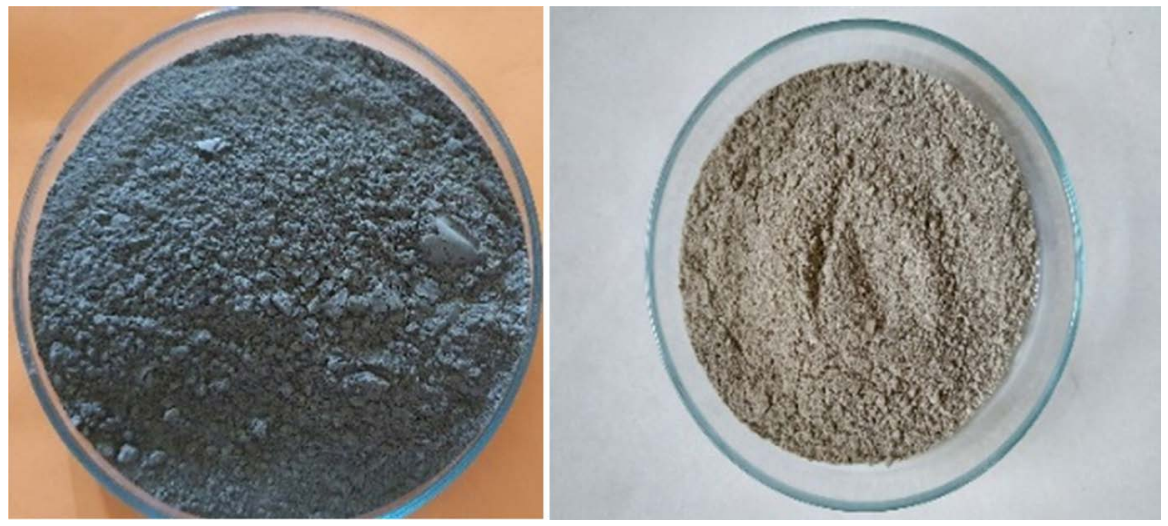

Figure 1. Physical appearance of CFA before (left) and after pre-treated with $\mathrm{NaOH}(\mathrm{s})$ (right). 


\subsection{Effectiveness of Si-Solubilizing Fungal Isolates on Soluble Si}

Silica solubilizing capacity was then assayed in $50 \mathrm{~mL}$ liquid and solid Bunt and Rovira medium with $0.25 \%(\mathrm{w} / \mathrm{v}) \mathrm{CFA}$ as $\mathrm{Si}$ source. Inoculation was performed by transferring two pieces of fungal inoculant ( $\varnothing=3 \mathrm{~mm} ; 10^{6}$ spores) on $250 \mathrm{~mL}$ Erlenmeyer flask containing $50 \mathrm{~mL}$ of liquid culture Bunt and Rovira medium. The cultures were incubated on a mechanical shaker at $100 \mathrm{rpm}\left(28^{\circ} \mathrm{C}\right)$ for four, eight, and twelve days. Silica solubilizing capacities were determined by using American Standard Testing and Material (ASTM D859-16) method. The dissolved silicate in the form of silicic acid $\left(\mathrm{H}_{2} \mathrm{SiO}_{4}\right)$ was measured using a spectronic 21 spectrophotometer at $660 \mathrm{~nm}$ wavelength [25].

\subsection{Effect of Organic Acids on Silica Dissolution}

This experiment was carried out to clarify the relative strength of different types of organic acids in solubilizing silica from CFA by using STM D859-16 method with colorimetric measurement. Citrate, acetate and oxalate were added separately in different concentrations $(0,100,200,300,400$ and $500 \mathrm{ppm})$ to $50 \mathrm{~mL}$ of Bunt and Rovira medium containing $0.25 \%(w / v)$ CFA, then incubated for eight days on a mechanical shaker at $100 \mathrm{rpm}$ in $28^{\circ} \mathrm{C}$. The dissolved silicate in the form of silicic acid $\left(\mathrm{H}_{2} \mathrm{SiO}_{4}\right)$ was measured using a spectronic 21 spectrophotometer at $660 \mathrm{~nm}$ wavelength [25].

\subsection{Effect of Citric Acid Produced by SSF Isolates on Silica Dissolution}

The SSF producing citric acid [19] [26] [27] was determined in liquid Bunt and Rovira with $0.25 \%(\mathrm{w} / \mathrm{v})$ CFA as sources of silica. Selected seven strains of SSF were grown in liquid Bunt and Rovira medium for four, eight, and twelve days, then incubated at a mechanical shaker at $100 \mathrm{rpm}$ in $28^{\circ} \mathrm{C}$. Citric acid assay was done according to improved pyridine-acetic anhydride acid method suggested by Marier and Boulet [28]. About $1 \mathrm{~mL}$ of pyridine and $5 \mathrm{~mL}$ of acetic anhydride added and incubated for $30 \mathrm{~min}$ in ice bath. The standard was prepared by different volumes of citric acid ( $100 \mathrm{mg}$ of citric acid was dissolved in $100 \mathrm{~mL}$ of deionized water (DW), i.e., $0.2-1 \mathrm{~mL}$ in 5 different test tubes. The volume was made up to $1 \mathrm{~mL}$ with DW. One milliliter of pyridine and $5 \mathrm{~mL}$ of acetic anhydride were added. The blank was prepared by taking $1 \mathrm{~mL}$ of DW in the place of citric acid. It was then kept for incubation in ice bath for 30 minutes. Concentration of citric acid was found by plotting graph of absorbance versus concentration and measured at $420 \mathrm{~nm}$ wavelength with the development of color density.

\section{Results and Discussion}

\subsection{Chemical Characteristic of CFA}

Selected chemical analyses were carried out to determine the element composition of CFA before and after treated by $\mathrm{NaOH}(\mathrm{s})$ as presented in Table 1 . The ash has an alkaline reaction with $\mathrm{pH} 9.5$ and contains $0.49 \%$ organic $\mathrm{C}, 0.02 \% \mathrm{~N}$, 
Table 1. Selected chemical properties of CFA originated from Bontang, East Kalimantan, Indonesia (un-treated and treated with alkaline).

\begin{tabular}{|c|c|c|}
\hline Chemical properties & Un-treated CFA & Treated CFA \\
\hline $\mathrm{pH} \mathrm{H}_{2} \mathrm{O}$ & 9.5 & 12.2 \\
\hline Organic Carbon (\%) & 0.49 & 0.24 \\
\hline Nitrogen (\%) & 0.02 & 0.01 \\
\hline $\mathrm{P}_{2} \mathrm{O}_{5} \mathrm{HCl} 25 \%(\%)$ & 0.53 & 0.11 \\
\hline $\mathrm{K}_{2} \mathrm{O} \mathrm{HCl} 25 \%(\%)$ & 0.1 & 0.12 \\
\hline $\mathrm{MgO} \mathrm{HCl} \mathrm{25 \%} \mathrm{( \% )}$ & 1.96 & 0.64 \\
\hline $\mathrm{CaO} 25 \%(\%)$ & 4.82 & 1.35 \\
\hline Sulphur (\%) & 0.1 & 0.28 \\
\hline $\mathrm{SiO}_{2}(\%)$ & 31.4 & 10.9 \\
\hline $\mathrm{H}_{4} \mathrm{SiO}_{4}(\%)$ & 0.008 & 2.50 \\
\hline $\mathrm{Al}_{2} \mathrm{O}_{3}(\%)$ & 28.16 & 8.6 \\
\hline $\mathrm{Fe}_{2} \mathrm{O}_{3}(\%)$ & 20.91 & 4.4 \\
\hline $\mathrm{Pb}(\mathrm{ppm})$ & 17.1 & 20.4 \\
\hline $\mathrm{Cd}(\mathrm{ppm})$ & 10.5 & 0.9 \\
\hline As (ppm) & n.d.* & n.d. \\
\hline $\mathrm{Hg}(\mathrm{ppm})$ & n.d. & n.d. \\
\hline $\mathrm{Cr}(\mathrm{ppm})$ & 326.8 & n.d. \\
\hline $\mathrm{Ni}(\mathrm{ppm})$ & 40.0 & 15.3 \\
\hline
\end{tabular}

${ }^{*}$ not detected.

0.53\% $\mathrm{P}_{2} \mathrm{O}_{5}, 0.10 \% \mathrm{~K}_{2} \mathrm{O}, 4.82 \% \mathrm{CaO}, 0.10 \% \mathrm{~S}, 31.4 \% \mathrm{SiO}_{2}, 0.008 \mathrm{ppm}_{4} \mathrm{SiO}_{4}$, $28.2 \% \mathrm{Al}_{2} \mathrm{O}_{3}$, and $20.9 \% \mathrm{Fe}_{2} \mathrm{O}_{3}$. All of these values are in the range of those reported by others previously [29]. A special notice should be paid on the very low value of soluble $\mathrm{Si}\left(\mathrm{H}_{4} \mathrm{SiO}_{4}\right)$ which far below $1 \mathrm{ppm}$ although the total silica $\left(\mathrm{SiO}_{2}\right)$ was considerably high $(31.4 \%)$. This is also the reason for the need to improve Si solubility of CFA by chemical and/or biological approaches. However, the alkaline treatment has improved the soluble Si content up to $2.5 \%$.

\subsection{Effect of CFA/NaOH on Soluble $\mathrm{Si}$}

Figure 2 shows the relationship between the amount $\mathrm{NaOH}(\mathrm{s})$ added to CFA and the total silica content, whereas Figure 3 indicates the effect of the alkaline to soluble Si of CFA. It is indicative that up to 60 grams of $\mathrm{NaOH}(\mathrm{s})$ added to 30 grams of CFA both total and soluble Si were linearly correlated. The more $\mathrm{NaOH}(\mathrm{s})$ added, the higher the values of total and soluble Si of the CFA. However, as the value of soluble Si from 30 grams addition of $\mathrm{NaOH}(\mathrm{s})$ has passed the minimum requirement for a commercial Si fertilizer set by the government (minimum $\mathrm{SiO}_{2} 10 \% \mathrm{w} / \mathrm{w}$ ), then the 1:1 ratio of CFA to $\mathrm{NaOH}(\mathrm{s})$ could be recommended as the best activation process for CFA to be Si fertilizer. As shown 


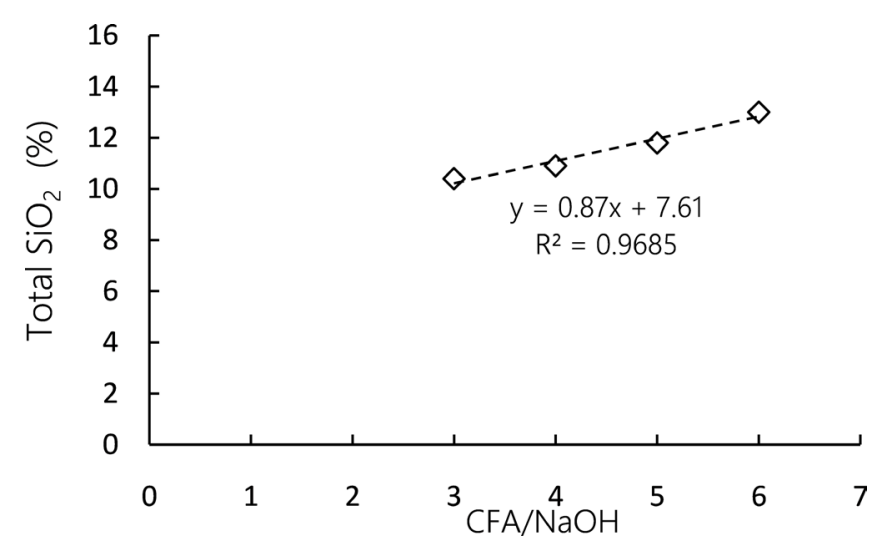

Figure 2. Effects of alkaline amount used for CFA pre-treatment on total $\mathrm{SiO}_{2}$ content yielded.

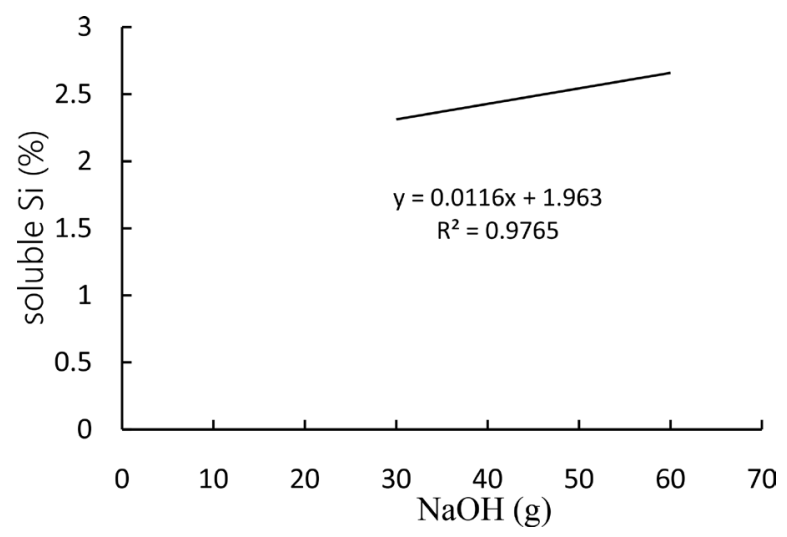

Figure 3. Effects of alkaline amounts used for CFA pre-treatment on soluble Si content yielded.

in Table 1, this treatment resulted in much better chemical compositions in term of soluble Si improved more than 300 times, decreased sesquioxide's and heavy metals contents in general. The increase of soluble $\mathrm{Si}$ is assumed to take place according to the following reaction [30].

\subsection{Changes on Mineralogical Properties}

Figure 4 shows the significant difference regarding the X-ray diffractograms between original and $\mathrm{NaOH}$-treated $\mathrm{CFA}$. The emergences of several strong intensity peaks were assumed due to the removal of contaminants, such as Al-Fe oxides, by alkaline solution treatment. These evidences were shown at the 2 degrees below 20 and above 30 . Silica minerals, particularly quartz, were indicated by $21.1(0.421 \mathrm{~nm})$ and $26.5^{\circ} 2(0.335 \mathrm{~nm})$ peaks [24] [31]. On the other hand, the peaks present in between 30 and $60^{\circ} 2$ could be considered as other characteristic peaks for quartz as reported by [32]. Alkaline pretreatment has yielded also consequently a disruption of CFA particles as shown by SEM observation. Figure 5 shows the physical appearances of particle of both original and $\mathrm{NaOH}$-treated CFA. Destruction of mineral surfaces could be assumed as the supporting evidence of increasing Si dissolution from CFA. 

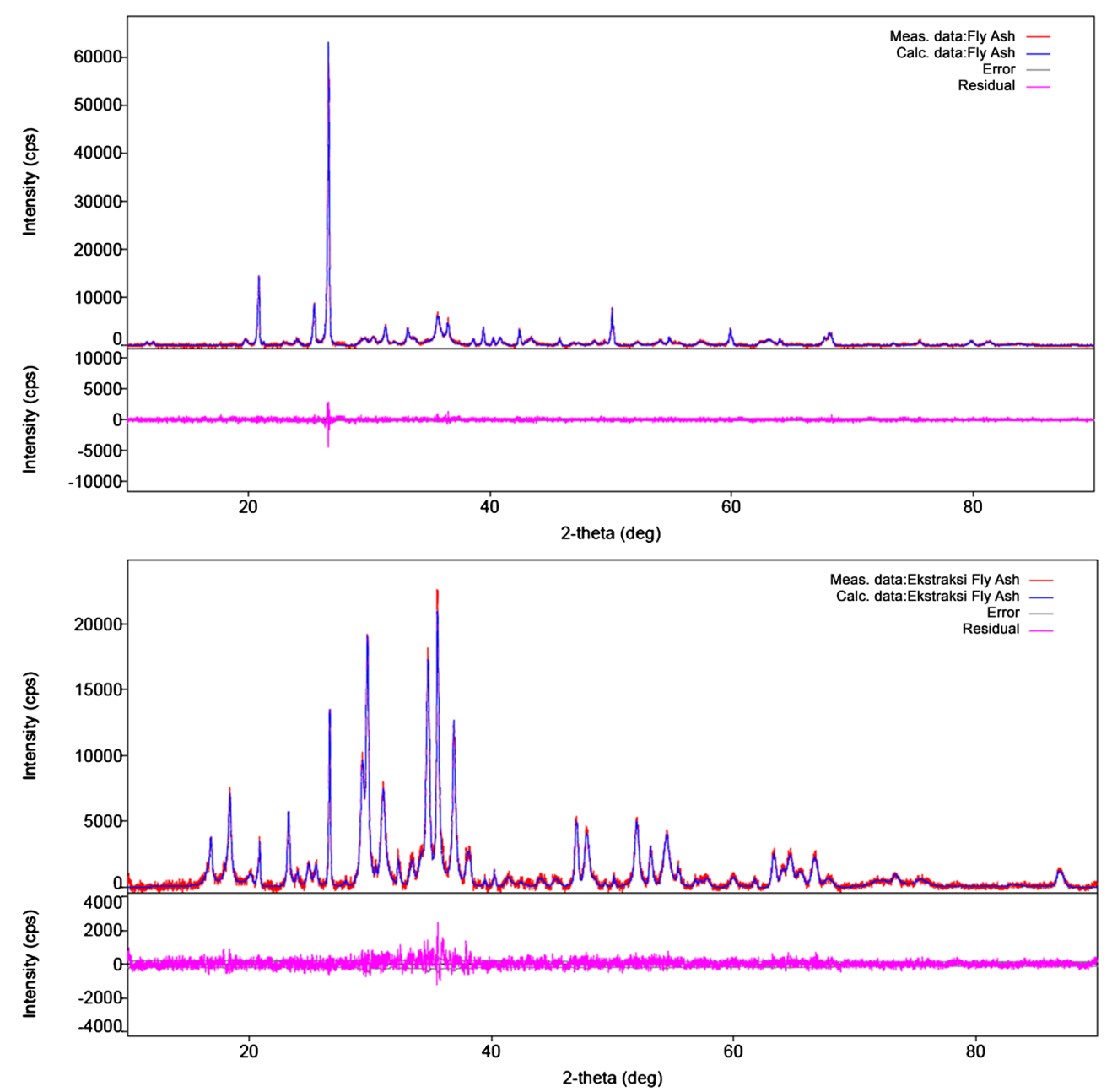

Figure 4. X-ray diffractograms of original (top) and $\mathrm{NaOH}$-treated (bottom) CFA indicating increased intensity of the mineral peaks of $\mathrm{Si}$ and others.
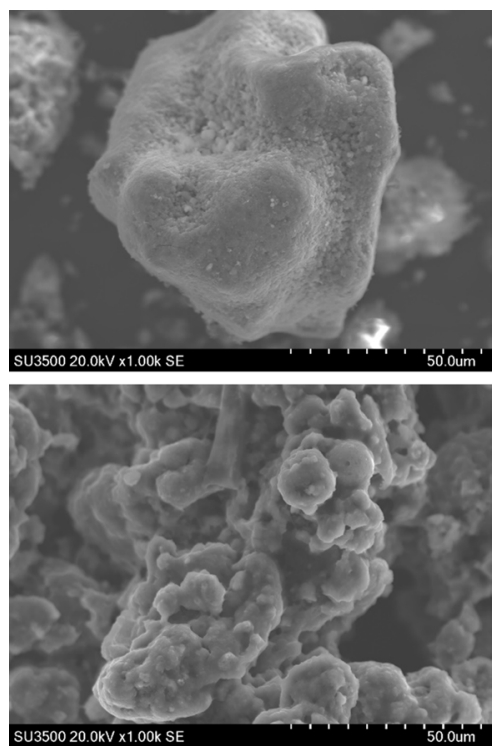

Figure 5. Scanning electron microscopy photographs of original (top) and $\mathrm{NaOH}$-treated (bottom) CFA. 


\subsection{Effectiveness of Si-Solubilizing Fungal (SSF) Isolates on Soluble $\mathrm{Si}$}

In order to improve further the solubility of Si from CFA we applied biological treatment by using selected Si-solubilizing fungus. Data shown in Table 2 indicate that among seven SSF isolates used in this experiment A. niger BCC 194 was the strongest isolate dissolving CFA resulting in the highest amount of soluble $\mathrm{Si}$ after twelve days of incubation. This evidence confirmed previous results reported by others in relation to the fact that SSF produces organic acid capable of solubilizing Si [19].

\subsection{Effect of Organic Acids on Silica Dissolution}

This experiment was carried out in laboratory to confirm the ability of organic acids as produced by SSF isolates in solubilizing Si from CFA. Data presented in Figure 6 show that there were linier relationships between three organic acids (i.e., oxalate, acetate, and citrate) concentrations and soluble-Si. It is indicative that oxalate was the strongest relationships as an agent for Si dissolution from CFA indicated by the highest coefficient of determination $\left(\mathrm{R}^{2}=0.984^{* *}\right)$ compared to the other two organic acids $\left(\mathrm{R}^{2}\right.$-acetate $=0.886^{* *}$ and $\mathrm{R}^{2}$-citrate $=$ $0.892^{* *}$ ) although the highest amount of soluble Si was obtained by citrate. Based on this evidence, the citrate was selected to be used in the next experiment.

\subsection{Effect of Citric Acid Producing SSF Isolates on Silica Dissolution}

In order to provide more supporting evidences regarding the capacity of citric acid produced by SSF isolates another experiment was carried out by growing each isolate on liquid culture media consisting CFA as the only Si source. Data shown in Table 3 indicate that during twelve days of incubation all isolates used produced citric acid with various concentrations. Isolate $A$. niger BCC F194 showed superiority compared to the other isolates by producing $801.5 \mathrm{ppm}$ at

Table 2. Soluble-Si from CFA by selecting SSF isolates during twelve days of incubation.

\begin{tabular}{cccc}
\hline Species & Day 4 & Day 8 & Day 12 \\
\hline Trichoderma sp & $22.58^{\mathrm{bc}}$ & $33.83^{\mathrm{d}}$ & $42.97^{\mathrm{d}}$ \\
T. viride & $17.13^{\mathrm{e}}$ & $54.40^{\mathrm{b}}$ & $63.02^{\mathrm{b}}$ \\
T. polysporum & $19.24^{\mathrm{de}}$ & $40.86^{\mathrm{c}}$ & $64.07^{\mathrm{b}}$ \\
T. pseudokoningii & $20.12^{\mathrm{cd}}$ & $53.17^{\mathrm{b}}$ & $64.07^{\mathrm{b}}$ \\
A. niger strain BCCF194 & $26.62^{\mathrm{a}}$ & $56.16^{\mathrm{b}}$ & $73.92^{\mathrm{a}}$ \\
A. niger strain Korbe 0909 & $23.28^{\mathrm{b}}$ & $60.91^{\mathrm{a}}$ & $76.73^{\mathrm{a}}$ \\
A. niger strain A1601 & $20.82^{\mathrm{bcd}}$ & $34.89^{\mathrm{d}}$ & $51.41^{\mathrm{c}}$ \\
Control (no isolate) & $14.31^{\mathrm{f}}$ & $17.30^{\mathrm{e}}$ & $19.76^{\mathrm{e}}$ \\
\hline
\end{tabular}

${ }^{*}$ Figures followed by the same letter(s) are not significantly different according to Duncan Multiple Range Test $(\mathrm{P}<0.05)$ 


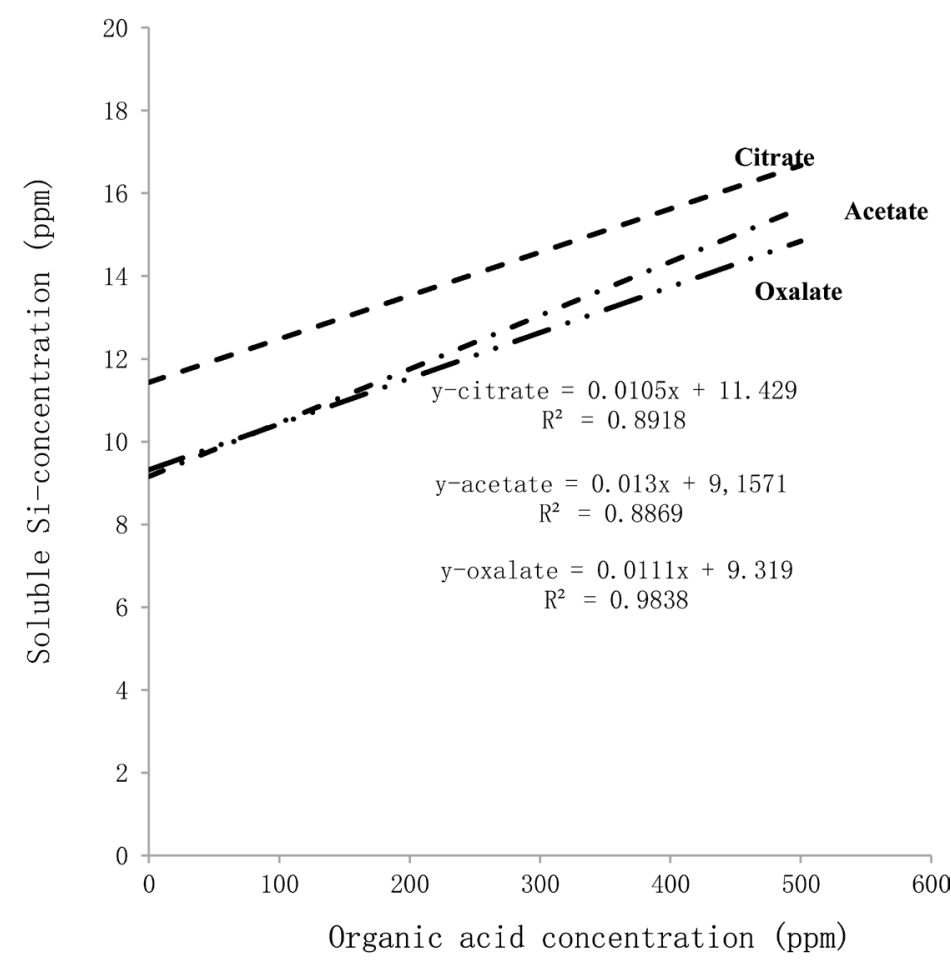

Figure 6. Relationships between selected organic acids concentrations and soluble-Si from CFA.

Table 3. Citric acid production by selected SSF isolates by using CFA as Si-source during twelve days of incubation period.

\begin{tabular}{cccc}
\hline Species & Day 4 & Day 8 & Day 12 \\
\hline Trichoderma sp & $439.0^{\mathrm{b}}$ & $511.5^{\mathrm{b}}$ & $591.5^{\mathrm{c}}$ \\
T. viride & $399.0^{\mathrm{b}}$ & $469.0^{\mathrm{c}}$ & $536.5^{\mathrm{d}}$ \\
T. polysporum & $431.5^{\mathrm{b}}$ & $471.5^{\mathrm{c}}$ & $534.0^{\mathrm{d}}$ \\
T. pseudokoningii & $421.5^{\mathrm{b}}$ & $521.5^{\mathrm{b}}$ & $629.0^{\mathrm{c}}$ \\
A. niger strain BCCF194 & $656.5^{\mathrm{a}}$ & $801.5^{\mathrm{a}}$ & $824.0^{\mathrm{a}}$ \\
A. niger strain Korbe 0909 & $634.0^{\mathrm{a}}$ & $774.0^{\mathrm{a}}$ & $724.0^{\mathrm{b}}$ \\
A. niger strain A1601 & $324.0^{\mathrm{c}}$ & $399.0^{\mathrm{d}}$ & $379.0^{\mathrm{e}}$ \\
Control (no isolate) & $296.0^{\mathrm{c}}$ & $334.0^{\mathrm{e}}$ & $321.5^{\mathrm{f}}$ \\
\hline
\end{tabular}

${ }^{*}$ Figures followed by the same letter(s) are not significantly different according to Duncan Multiple Range Test $(\mathrm{P}<0.05)$.

eight days and $824.0 \mathrm{ppm}$ citric acid at twelve days of incubation periods which are significantly higher than the other isolates. It is also indicative from these data that production of citric acids tended to reach optimum at eight days of incubation period. The correlation analysis (Figure 7) shows that a linier relationship exists between the citric acid concentration produced by SSF isolates and soluble Si from CFA. A significant correlation $\left(r=0.790-0.801^{* *}\right)$ during forth to twelve days of incubation period indicating that citric acid was predominant agent for solubilizing agent of Si from CFA. A relatively lower value of 


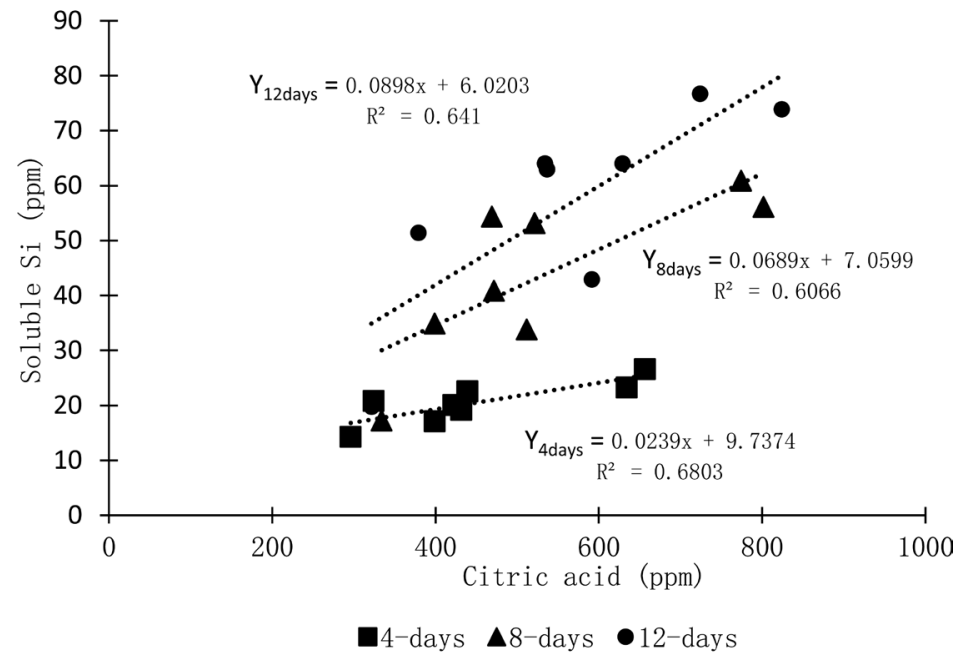

Figure 7. Correlation between citric acid produced by SSF and soluble Si from CFA at different incubation periods.

Table 4. Analytical results of CFA-derived Si fertilizer and its corresponding quality standard.

\begin{tabular}{|c|c|c|c|c|c|}
\hline \multirow[b]{2}{*}{ Parameter } & \multicolumn{3}{|c|}{ Results of Analyses } & \multirow[b]{2}{*}{$\begin{array}{c}\text { National } \\
\text { Quality } \\
\text { Standard }\end{array}$} & \multirow[b]{2}{*}{$\begin{array}{l}\text { Methods of } \\
\text { Analyses }\end{array}$} \\
\hline & $\begin{array}{c}\text { Raw } \\
\text { material }\end{array}$ & $\begin{array}{l}\text { Lab-scale } \\
\text { extraction }\end{array}$ & $\begin{array}{c}\text { Scale-up } \\
\text { extraction } \\
\left(120 \mathrm{~kg} \cdot \mathrm{batch}^{-1}\right)\end{array}$ & & \\
\hline $\mathrm{pH} \mathrm{H}_{2} \mathrm{O}$ & 9.52 & 12.2 & 12.7 & - & $\mathrm{pH}$ meter \\
\hline Nitrogen (\%) & 0.02 & 0.01 & 0.01 & - & Kjehdahl \\
\hline $\mathrm{P}_{2} \mathrm{O}_{5} \mathrm{HCl} 25 \%(\%)$ & 0.53 & 0.11 & 0.12 & - & Spectrophotometer \\
\hline $\mathrm{K}_{2} \mathrm{O}(\%)$ & 0.10 & 0.12 & 0.22 & - & AAS \\
\hline Sulfur (\%) & 0.1 & 0.28 & 0.22 & - & AAS \\
\hline Total $\mathrm{SiO}_{2}(\%)$ & 31.4 & 10.9 & 10.1 & Min. 10 & Gravimetry \\
\hline Soluble Si (\%) & 0.008 & 2.5 & 1.6 & - & Spectrophotometer \\
\hline Water content & 0.37 & 0.79 & 1.5 & Max. 5 & Gravimetry \\
\hline Organic Carbon & 0.49 & 0.24 & 0.25 & - & Spectrophotometer \\
\hline $\mathrm{MgO}(\%)$ & 1.96 & 0.64 & 0.99 & - & AAS \\
\hline $\mathrm{CaO}(\%)$ & 4.82 & 1.35 & 2.14 & - & AAS \\
\hline $\mathrm{Al}_{2} \mathrm{O}_{3}(\mathrm{ppm})$ & 28.16 & 8.60 & 8.97 & - & AAS \\
\hline $\mathrm{Fe}_{2} \mathrm{O}_{3}(\mathrm{ppm})$ & 20.91 & 4.4 & 7.5 & - & AAS \\
\hline $\mathrm{Pb}(\mathrm{ppm})$ & 17.1 & 20.4 & 32.6 & Max. 500 & AAS \\
\hline $\mathrm{Cd}(\mathrm{ppm})$ & 10.5 & 0.9 & 0.8 & Max. 100 & AAS \\
\hline As (ppm) & $\mathrm{nd}^{*}$ & nd & nd & Max. 100 & AAS \\
\hline $\mathrm{Hg}$ (ppm) & $\mathrm{Nd}$ & nd & nd & Max. 10 & AAS \\
\hline $\mathrm{Cr}(\mathrm{ppm})$ & 326.8 & nd & 6.2 & $<4 \%$ & AAS \\
\hline $\mathrm{Ni}(\mathrm{ppm})$ & 40 & 15.3 & 19.1 & $<0.4 \%$ & AAS \\
\hline
\end{tabular}

${ }^{*}$ not detected. 
$\mathrm{R}^{2}$ indicates that there were some other factors affecting the solubilization of $\mathrm{Si}$ from CFA and most likely due to acetate and/or oxalate contributions.

\subsection{Quality Standard of Si Fertilizer}

To be ably commercializing the product, quality of the Si fertilizer derived from CFA needs to be assessed by using authority's standard. Table 4 shows that currently existing quality standard for Si fertilizer are based on selected chemical parameters, such as total $\mathrm{SiO}_{2}$ content, water content, and selected heavy metals $(\mathrm{Pb}, \mathrm{Cd}, \mathrm{As}, \mathrm{Hg}, \mathrm{Cr}$, and $\mathrm{Ni}$ ) contents. Based on these characteristics the new Si-fertilizer formulated from CFA both at laboratory and scale-up production processes met the quality standard requirements set by the local authority for commercial uses.

\section{Conclusion}

Regardless of the current dispute regarding the use of CFA currently classified as a hazardous material for the environment, our current study revealed the potential use of CFA as Si fertilizer. Alkaline pre-treatment improved the solubility of hardly soluble Si resulting in increasing soluble Si content. A biological additional treatment by using SSF isolates proved to be beneficial in improving more the solubility of Si from CFA. Three organic acids (acetate, citrate, and oxalate) have been shown to be responsible for improved Si solubility. However, citric acid was more predominant compared to the other two. Based on the authority's quality standard, the new formulated Si fertilizer from CFA met the requirement as a commercial product.

\section{Acknowledgements}

The author wishes to thank the Indonesia Endowment Fund for Education (LPDP) Ministry of Finance Republic of Indonesia on the Productive Innovative Research program for valuable supports in funding this research (Contract No. PRJ-98/LPDP/2019, December 27, 2019).

\section{Conflicts of Interest}

The authors declare no conflicts of interest regarding the publication of this paper.

\section{References}

[1] Chanchal, M.C., Kapoor R. and Ganjewala, D. (2016). Alleviation of Abiotic and Biotic Stresses in Plants by Silicon Supplementation. Scientia Agriculturae, 13, 59-73. https://doi.org/10.15192/PSCP.SA.2016.13.2.5973

[2] Heckman, J. (2013) Silicon: A Beneficial Substance. Better Crops, 97, 14-16.

[3] Edward, B. (2014) Silicon Solutions. Sestante Edizioni, Bergamo, 184 p.

[4] Zhou, W., Apkarian, R., Wang, Z.L. and Joy, D. (2006) Fundamentals of Scanning Electron Microscopy (SEM). In: Zhou, W. and Wang, Z.L., Eds., Scanning Micro- 
copy for Nanotechnology, Techniques and Applications, Springer Science Business Media, New York, 1-40. https://doi.org/10.1007/978-0-387-39620-0_1

[5] Farooq, M., Wahid, A., Kobayashi, N., Fujita, D. and Basra, S.M.A. (2009) Plant Drought Stress: Effects, Mechanisms and Management. Agronomy for Sustainable Development, 29, 185-212. https://doi.org/10.1051/agro:2008021

[6] Ashraf, M. and Harris, P.J.C. (2013) Photosynthesis under Stressful Environments: An Overview. Photosynthetica, 51, 163-190. https://doi.org/10.1007/s11099-013-0021-6

[7] Amanah, D.M, Haris, N. and Santi, L.P. (2019) Physiological Responses of Bio-Silica-Treated Oil Palm Seedlings to Drought Stress. Menara Perkebunan, 87, 20-30. https://doi.org/10.22302/iribb.jur.mp.v87i1.306

[8] Santi, L.P, Mulyanto, D. and Goenadi, D.H. (2017) Double Acid-Base Extraction of Silicic Acid from Quartz Sand. Journal of Minerals and Materials Characterization and Engineering, 5, 362-373. https://doi.org/10.4236/jmmce.2017.56030

[9] Santi, L.P., Goenadi, D.H., Barus, J., Dariah, A. and Kalbuadi, D.N. (2019) Effects of Bio-Nano OSA Application on Fertilizer Use and Water Consumption Efficiencies of Black Soybean Grown on Rice-Field. Jurnal Tanah dan Iklim, 43, 105-112. https://doi.org/10.21082/jti.v43n2.2019.109-116

[10] Kalbuadi, D.N., Santi, L.P., Goenadi, D.H. and Barus, J. (2020) Application of Bio-Silicic Acid to Improve Yield and fertilizer Efficiency of Paddy on Tidal Swamp Land. Menara Perkebunan, 88, 111-119. https://doi.org/10.22302/iribb.jur.mp.v88i2.378

[11] Savant, N.K., Korndorfer, G.H., Datnoff, L.E. and Snyder, G.H. (1999) Silicon Nutrition and Sugarcane Production: A Review. Journal of Plant Nutrition, 22, 1853-1903. https://doi.org/10.1080/01904169909365761

[12] Amin, M., Ahmad, R., Ali, A., Aslam, M. and Lee, D.J. (2016) Silicon Fertilization improves the Maize (Zea mays L.) Performance under Limited Moisture Supply Cereal Research Communications, 44, 172-185. https://doi.org/10.1556/0806.43.2015.035

[13] Santi, L.P. (2019) Drought Tolerance Improvement of Oil Palm by Bio-Silicic Acid Application and Its Potential to Mitigate Climate Change. Proceedings of the International Seminar, Mataram, 16 November 2019, 227-240.

[14] Jala, S. and Goyal, D. (2006) Fly Ash as a Soil Ameliorant for Improving Crop Production-A Review. Bioresource Technology, 97, 1136-1147.

https://doi.org/10.1016/j.biortech.2004.09.004

[15] Shaheen, S.M., Hooda, P.S. and Tsadilas, C.D. (2014) Opportunities and Challenges in the Use of Coal Fly Ash for Soil Improvements-A Review. Journal of Environmental Management, 145, 249-267. https://doi.org/10.1016/j.jenvman.2014.07.005

[16] Blissett, R. S. and Rowson, R.A. (2012) A Review of the Multi-Component Utilization of Coal Fly Ash. Fuel, 97, 1-23. https://doi.org/10.1016/j.fuel.2012.03.024

[17] Argiz, C., Sanjuán, M.A. and Menéndez, E. (2017) Coal Bottom Ash for Portland Cement Production. Advances in Materials Science and Engineering, 2017, Article ID: 6068286. https://doi.org/10.1155/2017/6068286

[18] Gorai, S. (2018) Utilization of Fly Ash for Sustainable Environment Management. Journal of Materials and Environmental Science, 9, 385-393.

[19] Santi, L.P. (2020) Enhanced Solubilization of Insoluble Silicate from Quartz and Zeolite Minerals by Selected Aspergillus and Trichoderma Species. E-Journal Menara Perkebunan, 88, 79-89. https://doi.org/10.22302/iribb.jur.mp.v88i2.381 
[20] Mekkadinah, Suwarno, S., Garniwa, I. and Agustina, H. (2020) Review Regulation on the Determination of Fly Ash and Bottom Ash from Coal Fired Power Plant as Hazardous Waste in Effort to Increase Utilization in Indonesia. IOP Conference Series: Earth and Environmental Science, 519, Article ID: 012051. https://doi.org/10.1088/1755-1315/519/1/012051

[21] Vogl, J. and Ostermann, M. (2006) On the Measurement of the Moisture Content in Different Matrix Materials. Accreditation and Quality Assurance, 11, 356-362. https://doi.org/10.1007/s00769-006-0159-z

[22] Vasanthi, N., Saleena, L.M. and Raj, S.A. (2018) Silica Solubilization Potential of Certain Bacterial Species in the Presence of Different Silicate Minerals. Silicon, 10, 267-275. https://doi.org/10.1007/s12633-016-9438-4

[23] Akintokun, A.K, Akande, G.A. and Akintokun, P.O. (2007) Solubilization of Insoluble Phosphate by Organic Acid-Producing Fungi Isolated from Nigerian Soil. International Journal of Soil Science, 2, 301-307.

https://doi.org/10.3923/ijss.2007.301.307

[24] Brindley, G.W. and Brown, G. (1980) Crystal Structures of Clay Minerals and Their X-Ray Identification. Vol. 5, Mineralogical Society, London, 495 p. https://doi.org/10.1180/mono-5

[25] Rinder, T. and Oelkers, E.H. (2014) On the Colorimetric Measurement of Aqueous $\mathrm{Si}$ in the Presence of Organic Ligands and Common pH Buffering Agents. Mineralogical Magazine, 78, 1431-1436. https://doi.org/10.1180/minmag.2014.078.6.10

[26] Jamal, P., Alam, M.Z., Ramlan, M., Salleh, M. and Nadzir, M.M. (2005) Screening of Aspergillus for Citric Acid Production from Palm Oil Mill Effluent. Biotechnology, 4, 275-278. https://doi.org/10.3923/biotech.2005.275.278

[27] Marra, L.M., de Oliveira-Longatti, S.M., Soares, C.R.F.S., de Lima, J.M., Olivares, F.L. and Moreira, F.M.S. (2015) Initial pH of Medium Affects Organic Acids Production but Do Not Affect Phosphate Solubilization. Brazilian Journal of Microbiology, 46, 367-375. https://doi.org/10.1590/S1517-838246246220131102

[28] Chetan, D.M., Sarang, F.S., Nithin, N., Priyanka, N. and Bhat, R.S. (2018) Comparison of Citric Acid Production from Aspergillus niger in Solid and Suspension State Fermentation. International Journal of Green Pharmacy, 12, 502-509.

[29] Bhatt, A., Priyadarshinia, S., Mohanakrishnana, A.C., Abria, A., Sattlera, M. and Techapaphawitc, S. (2019) Physical, Chemical, and Geotechnical Properties of Coal Fly Ash: A Global Review. Case Studies in Construction Materials, 11, e00486. https://doi.org/10.1016/j.cscm.2019.e00263

[30] Crundwel, F.K. (2017) On the Mechanism of the Dissolution of Quartz and Silica in Aqueous Solutions. ACS Omega, 2, 1116-1127.

https://doi.org/10.1021/acsomega.7b00019

[31] Tan, K.H. (2005) Soil Sampling, Preparation and Analysis. 2nd Edition, CRC Press, Boca Raton, 672 p. https://doi.org/10.1201/9781482274769

[32] Zuo, R.F., Du, G.X., Yang, W.G., Liao, L.B and Li, Z. (2016) Mineralogical and Chemical Characteristics of a Powder and Purified Quartz from Yunnan Province. Open Geosciences, 8, 606-611. https://doi.org/10.1515/geo-2016-0055 